\title{
THE INFLUENCE OF HEAVY WORK INVESTMENT ON WORK OUTCOMES IN THE HOSPITALITY INDUSTRY IN SERBIA
}

\author{
Slobodan Čerović ${ }^{1 *}$, Ivana Blešić ${ }^{2,7}$, Jelena Tepavčević ${ }^{3}$, Svetlana Vukosav ${ }^{4}$, \\ Vuk Garača ${ }^{5}$ and Milan Bradić ${ }^{6}$ \\ ${ }^{1)}$ Singidunum University, Belgrade, Serbia \\ 2),3,4,,5,6) University of Novi Sad, Novi Sad, Serbia \\ ${ }^{7)}$ South Ural State University, Chelyabinsk, Russia
}

\begin{abstract}
Please cite this article as:
Čerović, S., Blešić, I., Tepavčević, J., Vukosav, S., Garača, V. and Bradić, M., 2020. The Influence of Heavy Work Investment on Work Outcomes in the Hospitality Industry in Serbia. Amfiteatru Economic, 22(Special Issue No. 14), pp. 1243-1264.
\end{abstract}

DOI: $10.24818 / \mathrm{EA} / 2020 / \mathrm{S} 14 / 1243$

\section{Article History}

Received: 27 June 2020

Revised: 20 August 2020

Accepted: 27 September 2020

\begin{abstract}
HWI is a phenomenon influencing individuals, their families, workplaces and society. The phenomenon is evidently present, especially among hospitality employees. The model proposed in this study included two fundamental sub-dimensions of HWI (time and effort) and its relationship with antecedents and outcomes. Data was gathered from 180 hospitality employees (hotels and restaurants) in Serbia. Taking several previous types of research as a basis, HWI (Work Investment and Time Commitment) was used as a mediational mechanism between antecedents and work outcomes of HWI. Hypotheses tested the relationships between constructs as well as the mediational role of HWI between antecedents and work outcomes. The results showed that HWI-WI is a full mediator of the relationship between work engagement and turnover intention, workaholism-WE and job satisfaction, and between workaholism-WC and job satisfaction. In the case of HWI-TC, the full mediated effect was confirmed in a relationship between work engagement and intent to leave the organization, workaholism-WC and job satisfaction as well as between workaholism-WC and job burnout. Theoretical and practical implications are discussed in the study.
\end{abstract}

Keywords: hospitality, heavy work investment, workaholism, work engagement, job burnout, turnover intentions

JEL Classification: J24, J63, L83, Z31

* Corresponding author, Slobodan Čerović - e-mail: scerovic@ singidunum.ac.rs 


\section{Introduction}

Contentment, cheerfulness, and prosperity of employees have a notable effect on the satisfaction of customers (Gamor, Amissah and Boakye, 2014) what is especially linked to the service sector owing to raised connection between employees and customers (Karatepe, 2011; Boz, et al., 2016) and nature of services transfer. Some authors observed service interactions as social exchanges (Koc and Bozkurt, 2017) whose results have a direct effect on a customer's comprehension of the service quality and their satisfaction (Koc, 2013; Boz and Y1lmaz, 2017). As a result, there is a high-level frequency of stress and other negative effects for employees in the service industry (Hsieh and Eggers, 2010), who display high emotional labor behavior which the business expects from them during the interaction with the customers, especially if there is a discrepancy between the displayed emotional behavior and the real feelings during this interaction (Yildiz, et al., 2014). Workers in the hospitality industry can build and maintain host-guest relationships (Onsøyen, et al., 2009) and build customer loyalty (Paeka, et al., 2015). Engagement of employees was found as a predictor of employee performance in service industries which can positively affect customer loyalty (Salanova, et al., 2005). Due to the simultaneity of production and consumption, as a result, there is an occurrence of transferring conditions of employees on customers, without filtration. Therefore, creating an appropriate environment for the service staff is a very important issue in providing quality service to consumers (Zaibaf, et al., 2013; Kang, et al., 2016). Collaboration between different departments and personnel, shortage of time, elastic demand, and labor-intensive function can be tiring for workers who have to deal with complex working procedures, demanding working tempo, and intensive interpersonal relations (Kuruuzum, et al., 2008). Besides, the hospitality industry is faced with persistent shortages of labor, an astonishingly high amount of fluctuation, as well with long working hours, and all of these aforementioned characteristics can be a cause of stress, burnout as well as dissatisfaction (Kuruuzum, et al., 2008). Hotel managers are also faced with long working hours (Pan, 2018) which results in higher dedication to the job (Jung and Yoon, 2016; Zopiatis, et al., 2014). Although the workaholic hotel managers list the job as the top priority, it is not unusual that they provide a friendly work environment for their employees thus helping them to achieve both work and personal goals (Pan, 2018). Thence, service companies have to provide contented and loyal personnel (García-Almeida, et al., 2015; Koc and Bozkurt, 2017) to respond to competitive pressures in dynamic markets.

In this sense, this research treats the HWI as a mediator variable in a relationship between antecedents of HWI (Workaholism, Work engagement and Income satisfaction) and Work Outcomes (Job satisfaction, Job burnout and Turnover intention). On the one hand, the outcomes can be positive such as job satisfaction (Mobaraki, et al., 2017; Ahmed and Khan, 2015), on the other job burnout (Huang and Miao, 2016; Chen, et al., 2012; Jung, et al., 2012) and intent to leave an organization represent the negative effects of HWI according to literature.

This research aimed to determine relationships between antecedents and outcomes of HWI through the mediational role of HWI in the hospitality industry. The paper is organized as follows. The literature review section is related to the description of the constructs used in this study and their relationships. By providing a literature background of study constructs, also justification for the selection of the hypotheses was provided. Subsequent sections deal with research methodology, results of testing hypotheses, and discussion of obtained 
results. Interpretation of obtained results was presented in the results section while the final part of this paper was reserved for the conclusion, theoretical and practical implications, study limitations as well as recommendations for future research and model extensions.

\section{Literature review}

Workaholism is referred to as "the tendency to work excessively hard and being obsessed with work, which manifests itself in working compulsively" (Schaufeli, Shimazu and Taris, 2009, p. 322). Several authors focused on the examination of the correlation between workaholism and work outcomes which are considered as negative, such as the presence of dissatisfaction with life, poor integration in social life after work (Bonebright, et al., 2000), strain derived from work, and complaints related to health (Burke, 2000). Moreover, employees who are workaholics do not gain more bonuses and rewards for their contributions compared to other employees (Burke, 2000). Contrastingly, numerous authors found a positive link between job satisfaction and workaholism (Burke, 1999; Shimazu and Schaufeli, 2009; Burke and MacDermid, 1999; Ng, et al., 2005). Also, the individual characteristics of an employee have a crucial role in the predisposition to become a workaholic, but here is a notable influence of organizational factors in the growth and observance of workaholism (Ng, Sorensen and Feldman, 2007).

Work engagement "refers to positive, fulfilling, work-related state of mind that is characterized by vigor, dedication, and absorption" (Schaufeli, et al., 2002, p.74). Contrary to workaholism, work engagement is correlated with outcomes that are considered as positive. Employees who are engaged are contented with their work and express higher dedication to the company (Schaufeli, et al., 2008). They find their job activities gratifying and amusing and feel job satisfaction (van Beek, et al., 2011, 2012). As a result, engaged employees may meet higher job description requirements (Schaufeli, et al., 2008; Van Beek, et al., 2012), which can affect the stimulation of employees for personal growth, education, and development (Bakker and Demerouti, 2007). Furthermore, engaged employees express higher satisfaction with life and health (Schaufeli and Salanova, 2007; Schaufeli, et al., 2008), they experience less work-family conflict (Bakker and Demerouti, 2007), their intention to leave the organization is decreased (Van Beek, 2013; Schaufeli and Bakker, 2004) and they experience lower work stress (Britt, Castro and Adler, 2005) which makes work engagement as an acceptable form of heavy work. Several studies identified that work engagement acts as a mediator between antecedents and resulting variables (Schaufeli and Bakker, 2004; Leung, et al., 2011; Saks, 2006; Maslach, et al., 2001).

Burnout is defined as "psychological syndrome of emotional exhaustion, depersonalization and reduced personal accomplishment that can occur among individuals who work with other people in some capacity“ (Maslach, 1993, p.70). Burnout of employees reflects in many implications, mainly for the organization, such as deleterious impacts on attitudes regarding the organization, performance of employees (Touringy, et al., 2013) as well as misbehavior (Lebrón, et al., 2018). Numerous papers examining workaholism found a positive link between job burnout and workaholism (Burke and Matthiesen, 2004; Schaufeli, et al., 2008), but some authors have reported a negative relationship between these two dimensions (Ulucan and Yavuz, 2019). Contrastingly, engaged employees have reported a lower amount of burnout (Schaufeli, et al., 2002; Schaufeli and Bakker, 2004; Crawford, LePine and Rich, 2010). 
Job satisfaction is defined as "a pleasurable or positive emotional state resulting from the appraisal of one's job or job experience" (Locke, 1976, p.1304). Workaholics are usually dissatisfied or unhappy employees. This can result in possible negative outcomes linked to low job satisfaction such as, increased intention to leave the organization, the presence of poorer performance at work as well as the absence of teamwork issues (Robinson, 1999; Spence and Robbins, 1992). On the other hand, a few researchers pointed out the fact that engaged employees are usually satisfied with their job (Garg, et al., 2017; Yen, 2013), contrary to workaholics (Schaufeli, et al., 2008; Van Beek, 2011, 2012). Previous studies indicated that job satisfaction is fostered by work engagement (Alarcon and Edwards, 2011; Saks, 2006; Giallonardo, et al., 2010)

Intent to quit is a willingness of employees to leave the organization (Kuvaas and Dysvik, 2010), which can be a consequence of lack of satisfaction with the job (Van Iddekinge, et al., 2011). Several studies found a positive correlation between workaholism and turnover intention (van Beek, et al., 2014; Andrews, 2019; Burke and MacDermid, 1999; Choi, 2013). Contrary to these results, the study carried out by Choi et al. (2013) indicated that with the increase of workaholism among employees, their intentions to leave the organization decrease. Moreover, several researchers identified a negative correlation between work engagement and intent to quit the organization (Halbesleben and Wheeler, 2008; Van Beek, et al., 2014; Schaufeli and Bakker, 2004). Compound measurement of work engagement was identified as a mediator of a relationship between intent to leave the organization and work resources (Schaufeli and Bakker, 2004).

In the context of the hospitality industry, several pieces of research have been conducted. For example, Yeh (2013) examined the relationship between work engagement and job satisfaction among Taiwan hotel employees. Their results confirmed the notable and positive influence of work engagement on job satisfaction. In another study, Karatepe and Demir (2014) found that hotel frontline employees with positive core self-evaluations express higher engagement in their work which positively influenced their ability to balance family and work roles. Jung and Yoon (2016) examined frontline employees in 5* hotels and family-style restaurants and found that work engagement acted as a mediator in a relationship between work importance and commitment to the organization. Park and Gursoy (2012) found that generational membership of hotel employees significantly influenced the engagement of employees. Besides this, they found that generational differences moderated the relationship between engagement of employees and their intention to leave the organization. Lu et al. (2015) determined employee position as a moderator in a relationship between work dedication and turnover intentions and absorption and job satisfaction. Ulucan and Yavuz (2019) examined the correlation between workfamily conflict, workaholism, and burnout among hotel employees. They indicated that a higher level of work-family conflict is a consequence of an increase in workaholism. Furthermore, a higher level of work-family conflict increases employees' burnout.

Based on this, the following hypotheses were drawn:

- $\mathbf{H}_{1}$ : There is a positive connection between workaholism and job satisfaction;

- H2: There is a negative connection between work engagement and turnover intention;

- H3: There is a positive relationship between workaholism and job burnout;

- H4: There is a negative relationship between work engagement and job burnout; 
- H5: There is a positive relationship between work engagement and job satisfaction;

- H6: There is a positive relationship between workaholism and turnover intention.

To explain the reasons for the occurrence of these negative phenomena in the service sector, as a consequence of hard work, the concept of heavy work investment (HWI) was introduced by Snir and Harpaz (2012). This concept consists of two sub-dimensions, more precisely Work Intensity (WI) and Time Commitment (TC) which distinguish the concept of HWI and working hours itself (Snir and Harpaz, 2015; Green, 2008). Many authors dealt with issues of working overtime and heavy work investment (Stimpfel, et al., 2012; Caruso, 2014), as well as reasons for it, such as degree of education, employers' requests, addiction to work, financial needs, devotion to work, work passion as well as obsessive-compulsive personality and more (Snir and Harpaz, 2012, 2015). HWI can affect different outcomes, such as interference of work and family life, health, work satisfaction and productivity, thus, HWI can be discussed as a mediator variable (Burke and Fiksenbaum, 2009a, 2009b; Raediker, et al., 2006; Dembe, et al., 2005; Bonebright, et al., 2000). Starting from the point that HWI (time and effort) will act as a mediator of the relationship between antecedents of HWI (WE, W-WE, W-WC, IS) and work outcomes (JS, JB, TI), we expect that:

- H7: HWI-WI is a mediator of the relationship between workaholism (W-WE and WWC) and turnover intentions;

- H8: HWI-WI is a mediator of the relationship between work engagement and job burnout;

- H9: HWI-TC is as a mediator of the relationship between work engagement and job burnout.

- H10: HWI-TC is a mediator of the relationship between work engagement and job satisfaction.

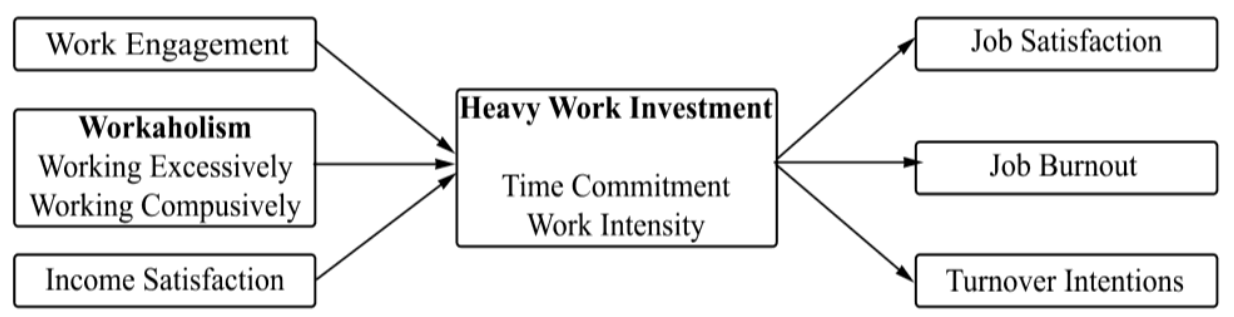

Figure no. 1. Research model

\section{Research Methodology}

\subsection{Participants and procedure}

The online survey was used to obtain data among the employees in the Serbian hospitality industry. The research was conducted in the period March-June 2020. The questionnaire was created using Google forms and sent to email addresses of 20 high-class hotels $\left(4^{*}\right.$ and $\left.5^{*}\right)$ 
and 30 fine dining restaurants in the most popular mountain (Zlatibor), spa (Vrnjačka Banja), and urban (Beograd and Novi Sad) destinations in Serbia (https://www.tripadvisor.com/Tourism-g294471-Serbia-Vacations.html). A sample of 180 employees (30.6\% in hotels and $69.4 \%$ in restaurants) was obtained in this manner. First of all, hotel and restaurant managers were contacted with a request to help this research by asking their employees to participate in the survey. The anonymity of objects and employees has been guaranteed. The sample consists of the employees working in different positions and different departments. The sociodemographic characteristics of employees are presented in Table 1.

Table no. 1. Sociodemographic characteristics of respondents

\begin{tabular}{|l|c|c|}
\hline \multicolumn{1}{|c|}{ Sociodemographic characteristics } & Frequency & Percentage \\
\hline Gender & $\mathbf{9 8}$ & $\mathbf{5 4 . 4}$ \\
Male & $\mathbf{8 2}$ & $\mathbf{4 5 . 6}$ \\
Female & & \\
\hline Age & 43 & 23.9 \\
Up to 25 & 75 & 41.7 \\
$26-35$ & 43 & 23.9 \\
$36-45$ & 19 & 10.6 \\
$46-55$ & & \\
\hline Education level & 110 & 61.1 \\
High school & 24 & 13.3 \\
College & 34 & 18.9 \\
Faculty & 12 & 6.7 \\
Master/Magistrate & & \\
\hline Marital status & 67 & 37.2 \\
Married & 113 & 62.8 \\
Single & & \\
\hline Working in & 55 & 30.6 \\
Hotel & 125 & 69.4 \\
Restaurant & & \\
\hline
\end{tabular}

\subsection{Instruments}

A questionnaire consisting of two parts was created for this study. The first part of the questionnaire refers to the sociodemographic characteristics of employees (gender, age, education level, marital status, type of working facility). The second part of the questionnaire was composed of items designed for measuring selected constructs.

The longer version of the UWES (Utrecht Work Engagement Scale) was used for measuring the engagement of employees at their work (Schaufeli et al., 2002). The longer 17-item version of the UWES is divided into three subscales: vigor, absorption, and dedication. The workaholism of employees was evaluated by the DUWAS (Dutch Work Addiction Scale) which had been developed by Schaufeli et al. (2009a). Originally, the DUWAS is made of two subscales consisting of five items each: WE (Working Excessively) and WC (Working Compulsively). By factor analysis (Table 3), these two subscales were separated into two factors, so their influences will be considered separately 
in further analyses. The work satisfaction scale by Cammann et al. (1979) was used for measuring job satisfaction. This scale has three items. Burnout was evaluated using a 6item by Lin et al. (2014). The intention of employees to quit the organization was evaluated by scale adopted from Vandenberghe and Bentein (2009). The scale consists of three items. Two dimensions of the HWI concept developed by Snir and Harpaz (2012) and adapted from the same study were employed in this research. Work intensity and Time commitment were assessed using five items for each construct (Brown and Leigh, 1996). The satisfaction of employees with their incomes (income satisfaction) was measured using a single item ( 1 - absolutely dissatisfied, 5 - absolutely satisfied). Measurement items are presented in table 2 .

Table no. 2. Measurement items

\begin{tabular}{|c|c|c|}
\hline Factor & $\begin{array}{l}\text { Number } \\
\text { of items }\end{array}$ & Source \\
\hline $\begin{array}{c}\text { Work engagement (UWES - Utrecht Work } \\
\text { Engagement Scale) - } 3 \text { subscales: } \\
\text { Vigor } \\
\text { Absorption } \\
\text { Dedication }\end{array}$ & $\begin{array}{c}17 \\
6 \\
6 \\
5\end{array}$ & $\begin{array}{l}\text { Schaufeli, et al., } \\
\qquad(2002)\end{array}$ \\
\hline $\begin{array}{c}\text { Workaholism (DUWAS - Dutch Work Addiction } \\
\text { Scale) - } 2 \text { subscales: } \\
\text { working compulsively } \\
\text { working excessively }\end{array}$ & $\begin{array}{c}10 \\
5 \\
5\end{array}$ & $\begin{array}{l}\text { Schaufeli, et al. } \\
\qquad(2009 \mathrm{a})\end{array}$ \\
\hline Job Satisfaction (Work satisfaction scale) & 3 & $\begin{array}{c}\text { Cammann, et al. } \\
\text { (1979) }\end{array}$ \\
\hline Job Burnout & 6 & Lin, et al. (2014) \\
\hline Turnover Intention & 3 & $\begin{array}{c}\text { Vandenberghe and } \\
\text { Bentein (2009) } \\
\end{array}$ \\
\hline $\begin{array}{c}\text { Heavy Work Investment }-2 \text { subscales: } \\
\text { work intensity } \\
\text { time commitment }\end{array}$ & $\begin{array}{c}\mathbf{1 0} \\
5 \\
5\end{array}$ & $\begin{array}{l}\text { Snir and Harpaz } \\
\text { (2012); Brown and } \\
\text { Leigh, (1996) }\end{array}$ \\
\hline
\end{tabular}

*5-point Likert scale: absolutely disagree (1) to absolutely agree (5)

\section{Results}

\subsection{Results of Factor analysis}

The method of principal components was used for data factor analysis and derivation of sub-dimensions and Varimax rotation was applied. In this research, all sub-dimensions which exceeded eigenvalue 1 and had factor loadings greater than 0.3 were detained. The results of the applied factor analysis, which proposed an eight-factor solution, incorporated 49 items and elucidated $73.51 \%$ of the variation. The Kaiser-Meyer-Olkin (KMO) overall measure of the adequacy of the sample was 0.92, which was middling (Kaiser, 1974), and Bartlett's test (Bartlett, 1950, 1951) of sphericity was notable ( $\mathrm{p}=0.000)$. The results of the applied factor analysis generated a clear structure of factors with relatively high loadings on the suitable factors. The values of Cronbach's $\alpha$ for each factor exceeded 0.7 . The obtained results showed that the alpha coefficient for these eight factors ranged from 0.827 to 0.963 . 
This indicated that the scales used in the questionnaire had considerable reliability (Nunnally, 1978). Table 3 illustrates the obtained results and items within isolated factors.

Table no. 3. Results of factor analysis

\begin{tabular}{|c|c|c|c|c|c|}
\hline 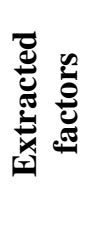 & Items & $\begin{array}{l}\text { Factor } \\
\text { loading }\end{array}$ & 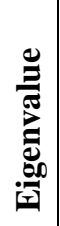 & 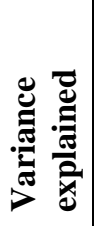 & 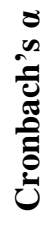 \\
\hline \multirow{17}{*}{ 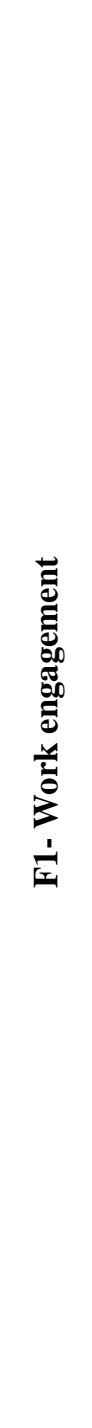 } & At my work, I feel bursting with energy y. & .800 & \multirow{17}{*}{ 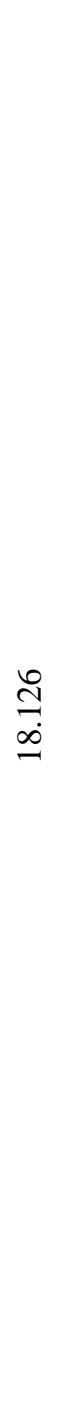 } & \multirow{17}{*}{ 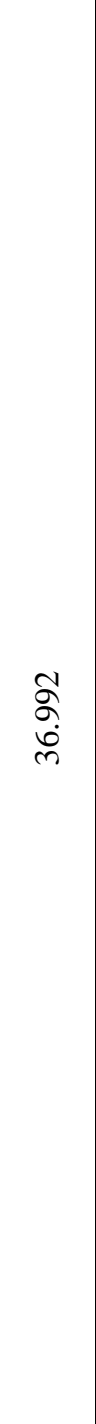 } & \multirow{17}{*}{$m$} \\
\hline & $\begin{array}{l}\text { I find the work that I do full of meaning and } \\
\text { purpose. }\end{array}$ & .712 & & & \\
\hline & Time flies when I am working. & .605 & & & \\
\hline & At my job, I feel strong and vigorous. & .805 & & & \\
\hline & I am enthusiastic about my job. & .806 & & & \\
\hline & $\begin{array}{l}\text { When I am working, I forget everything else } \\
\text { around me. }\end{array}$ & .686 & & & \\
\hline & My job inspires me. & .861 & & & \\
\hline & $\begin{array}{l}\text { When I get up in the morning, I feel like going to } \\
\text { work. }\end{array}$ & .821 & & & \\
\hline & I feel happy when I am working intensely. & .778 & & & \\
\hline & I am proud of the work that I do. & .738 & & & \\
\hline & I am immersed in my work. & .781 & & & \\
\hline & $\begin{array}{l}\text { I can continue working for very long periods at a } \\
\text { time. }\end{array}$ & .695 & & & \\
\hline & To me, my job is challenging. & .745 & & & \\
\hline & I get carried away when I am working. & .733 & & & \\
\hline & At my job, I am very resilient, mentally. & .615 & & & \\
\hline & It is difficult to detach myself from my job. & .741 & & & \\
\hline & $\begin{array}{l}\text { At my work, I always persevere, even when } \\
\text { things do not go well. }\end{array}$ & .567 & & & \\
\hline
\end{tabular}




\begin{tabular}{|c|c|c|c|c|c|}
\hline 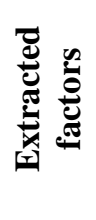 & Items & $\begin{array}{l}\text { Factor } \\
\text { loading }\end{array}$ & 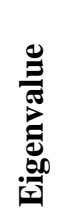 & 宸 & 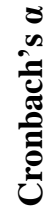 \\
\hline \multirow{5}{*}{ 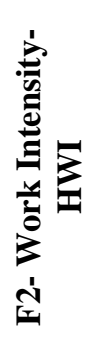 } & $\begin{array}{l}\text { When there's a job to be done, I devote all my } \\
\text { energy to getting it done. }\end{array}$ & .695 & \multirow{5}{*}{$\underset{8}{8}$} & \multirow{5}{*}{\begin{tabular}{l}
\multirow{2}{n}{} \\
$\stackrel{n}{n}$
\end{tabular}} & \multirow{5}{*}{ a } \\
\hline & When I work, I do so with intensity. & .644 & & & \\
\hline & I work at my full capacity in all of my job duties. & .626 & & & \\
\hline & $\begin{array}{l}\text { I strive as hard as I can to be successful in my } \\
\text { work. }\end{array}$ & .691 & & & \\
\hline & When I work, I really exert myself to the fullest. & .617 & & & \\
\hline \multirow{5}{*}{ 疍 } & Other people know me by the long hours I keep. & .707 & \multirow{5}{*}{$\begin{array}{l}\frac{\infty}{\sigma} \\
i\end{array}$} & \multirow{5}{*}{$\stackrel{m}{m}$} & \multirow{5}{*}{$\stackrel{\infty}{8}$} \\
\hline & $\begin{array}{l}\text { My clients know I'm in the office early and } \\
\text { always leave late. }\end{array}$ & .730 & & & \\
\hline & $\begin{array}{l}\text { Among my peers, I'm always the first to arrive } \\
\text { and the last to leave. }\end{array}$ & .765 & & & \\
\hline & $\begin{array}{l}\text { Few of my peers put in more hours weekly than I } \\
\text { do. }\end{array}$ & .875 & & & \\
\hline & $\begin{array}{l}\text { I put in more hours throughout the year than most } \\
\text { of our salespeople do. }\end{array}$ & .823 & & & \\
\hline \multirow{5}{*}{ 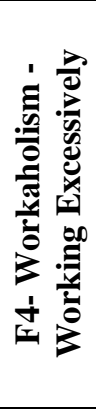 } & $\begin{array}{l}\text { I seem to be in a hurry and racing against the } \\
\text { clock. }\end{array}$ & .636 & \multirow{5}{*}{$\stackrel{m}{m}$} & \multirow{5}{*}{ 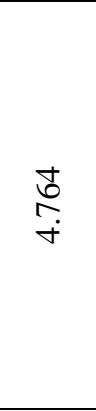 } & \multirow{5}{*}{$\varkappa_{\infty}$} \\
\hline & $\begin{array}{l}\text { I find myself continuing to work after my } \\
\text { coworkers have called it quits. }\end{array}$ & .715 & & & \\
\hline & I stay busy and keep many irons in the fire. & .750 & & & \\
\hline & $\begin{array}{l}\text { I spend more time working than socializing with } \\
\text { friends or enjoying hobbies, or leisure activities. }\end{array}$ & .762 & & & \\
\hline & $\begin{array}{l}\text { I find myself doing two or three things at one time } \\
\text { such as eating lunch and writing a memo while } \\
\text { taking on the telephone. }\end{array}$ & .698 & & & \\
\hline \multirow{6}{*}{ 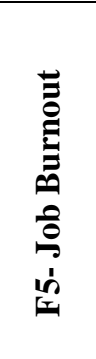 } & I feel emotionally drained from my work. & .808 & \multirow{6}{*}{  } & \multirow{6}{*}{ 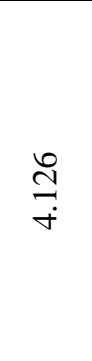 } & \multirow{6}{*}{$\underset{\infty}{\infty}$} \\
\hline & I feel used up at the end of the workday. & .782 & & & \\
\hline & I feel burned out from my work. & .787 & & & \\
\hline & $\begin{array}{l}\text { I feel I treat some customers as if they are } \\
\text { impersonal "objects". }\end{array}$ & .640 & & & \\
\hline & $\begin{array}{l}\text { I feel I have become uncaring toward people since } \\
\text { I took this job. }\end{array}$ & .591 & & & \\
\hline & I worry that this job is hardening me emotionally. & .566 & & & \\
\hline
\end{tabular}




\begin{tabular}{|c|c|c|c|c|c|}
\hline 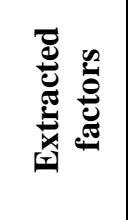 & Items & $\begin{array}{l}\text { Factor } \\
\text { loading }\end{array}$ & 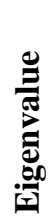 & 异 & 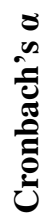 \\
\hline \multirow{5}{*}{ 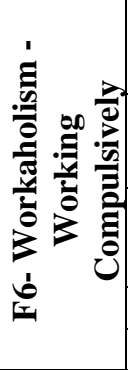 } & $\begin{array}{l}\text { It is important to me to work hard even when I do } \\
\text { not enjoy what I am doing. }\end{array}$ & .516 & \multirow{5}{*}{ 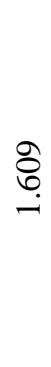 } & \multirow{5}{*}{$\underset{\infty}{\infty}$} & \multirow{5}{*}{$\underset{\infty}{\infty}$} \\
\hline & $\begin{array}{l}\text { I feel that there is something inside me that drives } \\
\text { me to work hard. }\end{array}$ & .490 & & & \\
\hline & $\begin{array}{l}\text { I feel obliged to work hard, even when it is not } \\
\text { enjoyable. }\end{array}$ & .736 & & & \\
\hline & I feel guilty when I take time off work. & .834 & & & \\
\hline & It is hard for me to relax when I am not working. & .714 & & & \\
\hline \multirow{3}{*}{ 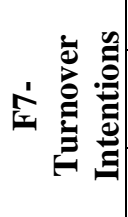 } & I often think about quitting this organization. & .803 & \multirow{3}{*}{ 导 } & \multirow{3}{*}{$\stackrel{n}{n}$} & \multirow{3}{*}{ Әે } \\
\hline & $\begin{array}{l}\text { I intend to search for a position with another } \\
\text { employer within the next year. }\end{array}$ & .905 & & & \\
\hline & I intend to quit my organization soon. & .888 & & & \\
\hline \multirow{3}{*}{ 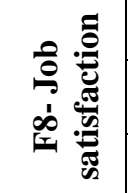 } & All in all, I am satisfied with my job. & .558 & \multirow{3}{*}{ กิ } & \multirow{3}{*}{ 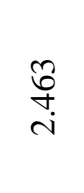 } & \multirow{3}{*}{$\widehat{\infty}$} \\
\hline & In general, I don't like my job. * & .846 & & & \\
\hline & In general, I like working here. & .808 & & & \\
\hline
\end{tabular}

*reversible coded item

\subsection{The results of the regression analysis}

Standard linear regression (Fox, 2015) was conducted to analyze the influence of work engagement, workaholism and income satisfaction on heavy work investments (work intensity and time commitment) and work outcomes (job satisfaction, job burnout, and intention to leave the organization). In the second part of the research, the additional analyses were applied to analyze the possible mediating effect of heavy work investments between work engagement, workaholism, income satisfaction and work outcomes. The results are presented in Table 4.

Table no. 4. The results of the regression analysis between work engagement, workaholism, income satisfaction, and heavy work investments (HWI)

\begin{tabular}{|l|c|c|c|c|}
\hline \multirow{2}{*}{\multicolumn{1}{|c|}{ Independent variable }} & \multicolumn{4}{c|}{ Dependent variable - Work intensity (HWI) } \\
\cline { 2 - 5 } & $\mathbf{R}^{\mathbf{2}}$ & $\mathbf{F}$ & Sig. & $\boldsymbol{\beta}$ \\
\hline Work Engagement & .566 & 231.849 & .000 & $.752^{* *}$ \\
\hline Workaholism - Working Excessively & .241 & 56.146 & .000 & $.491^{* *}$ \\
\hline Workaholism - Working Compulsively & .339 & 91.136 & .000 & $.582^{* *}$ \\
\hline Income Satisfaction & .030 & 5.465 & .021 & $.173^{*}$ \\
\hline
\end{tabular}




\begin{tabular}{|l|c|c|c|c|}
\hline \multirow{2}{*}{\multicolumn{1}{c|}{ Independent variable }} & \multicolumn{4}{c|}{ Dependent variable - Work intensity (HWI) } \\
\cline { 2 - 5 } & $\mathbf{R}^{\mathbf{2}}$ & $\mathbf{F}$ & \multicolumn{1}{c|}{ Sig. } & $\boldsymbol{\beta}$ \\
\hline Independent variable & Dependent variable - Time Commitment (HWI) \\
\hline Work Engagement & .268 & 65.240 & .000 & $.518^{* *}$ \\
\hline Workaholism - Working Excessively & .181 & 39.146 & .000 & $.426^{* *}$ \\
\hline Workaholism - Working Compulsively & .136 & 28.066 & .000 & $.369^{* *}$ \\
\hline Income Satisfaction & .004 & .713 & .399 & .063 \\
\hline
\end{tabular}

$* \beta$ is significant at 0.05 ; level $* * \beta$ is significant at 0.01 level

The results within Table 4 show that almost all analyzed factors which are antecedents of HWI (WE, W-WE, W-WC, and IS) had a significant positive influence on employees' heavy work investment expressed through time investment and work intensity (effort). Considering the effects of independent variables on HWI-WI, the highest variance $(56.6 \%)$ can be explained by work engagement, which means that higher intensity of work manifested by an employee results in an increased engagement at work. Besides, the influence of W-WC $(33.9 \%)$ is also significant. Since hospitality is a labor-intensive industry, customer satisfaction depends on the quality of service provided by employees (Boz and Y1lmaz, 2017). Practically, this can lead to the conclusion that the compulsivity of employees is triggered by their obligation to provide excellent service in a demanding work environment and to create a long-term positive image of the company. Also, this can affect employees' self-image perception which increases their job performance and it can be considered as a potential motivational factor caused by goals expected to be achieved in the workplace. If we consider the effects of independent variables on HWI-TC, WE explains $26.8 \%$ of the variance. This means that an increase in work engagement leads to an increase in the time invested in performing work tasks. The influence of both subdimensions of workaholism is also significant but the influence of IS on HWI-TC is not significant.

The results within Table 5 show the influence of antecedents of HWI (WE, workaholismWC and IS, HWI-WI and HWI-TC) on work outcomes (JS, TI and JB).

Table no. 5. Regression between work engagement, workaholism, income satisfaction, heavy work investments and work outcomes

\begin{tabular}{|l|c|c|c|c|}
\hline \multicolumn{1}{|c|}{ Independent variable } & $\mathbf{R}^{\mathbf{2}}$ & \multicolumn{1}{c|}{ F } & \multicolumn{1}{c|}{ Sig. } & $\boldsymbol{\beta}$ \\
\hline & \multicolumn{5}{c|}{ Job Satisfaction } \\
\hline Work Engagement & .265 & 64.333 & .000 & $.515^{* *}$ \\
\hline Workaholism - Working Excessively & .002 & .345 & .558 & .044 \\
\hline Workaholism - Working Compulsively & .034 & 6.321 & .000 & $.013^{*}$ \\
\hline Income Satisfaction & .278 & 68.393 & .000 & $.527^{* *}$ \\
\hline Work intensity (HWI) & .227 & 52.340 & .000 & $.477^{* *}$ \\
\hline Time commitment (HWI) & .055 & 10.343 & .002 & $.234^{* *}$ \\
\hline & \multicolumn{5}{|c|}{ Turnover Intention } \\
\hline Work Engagement & .002 & .282 & .596 & -.040 \\
\hline Workaholism - Working Excessively & .088 & 17.096 & .000 & $.297^{* *}$ \\
\hline Workaholism - Working Compulsively & .052 & 9.748 & .002 & $.228^{* *}$ \\
\hline Income Satisfaction & .003 & .514 & .474 & .054 \\
\hline Work intensity (HWI) & .017 & 2.987 & .086 & .128 \\
\hline Time commitment (HWI) & .027 & 4.996 & .027 & $.165^{*}$ \\
\hline
\end{tabular}




\begin{tabular}{|l|c|c|c|c|}
\hline \multicolumn{1}{|c|}{ Independent variable } & $\mathbf{R}^{\mathbf{2}}$ & \multicolumn{1}{c|}{ F } & Sig. & $\boldsymbol{\beta}$ \\
\hline & \multicolumn{4}{|c|}{ Job Burnout } \\
\hline Work Engagement & .000 & .059 & .809 & -.018 \\
\hline Workaholism - Working Excessively & .167 & 35.597 & .000 & $.409^{* *}$ \\
\hline Workaholism - Working Compulsively & .036 & 6.687 & .011 & $.190^{*}$ \\
\hline Income Satisfaction & .008 & 1.412 & .236 & -.089 \\
\hline Work intensity (HWI) & .006 & 1.061 & .304 & .077 \\
\hline Time commitment (HWI) & .034 & 6.283 & .013 & $.185^{*}$ \\
\hline
\end{tabular}

$* \beta$ is significant at 0.05 ; level $* * \beta$ is significant at 0.01 level

In the case of JS, the positive influence of IS is notable. Jobs in the hospitality industry are characterized by a low level of income (Pizam, 2015), which practically means that an increase in income leads to an increase in job satisfaction. Significant positive effects are present between JS and WE and JS and HWI-WI. An increase in engagement expressed by employees influences an increase in job satisfaction. Additionally, higher investment in work increases the job satisfaction of employees. Considering the effects of independent variables on TI, it can be concluded that there are notable positive effects of two subdimensions of workaholism (WE and WC), as well as positive effects of HWI-TC on TI. In other words, the more time an employee spends doing the job, the intention to leave the organization is higher. $\mathrm{W}-\mathrm{WE}$ has a notable positive effect on $\mathrm{JB}$, as well as $\mathrm{W}-\mathrm{WC}$. An increase in the workaholism level leads to an increase in the burnout of employees. The influence of HWI-TC on JB is also significant and positive (Rabenu et al., 2019), whereas the influence of HWI-WI on JB is not significant.

\subsection{Mediating effect of heavy work investment between work engagement, workaholism, financial satisfaction and work outcomes}

The mediating role of the employees' HWI-WI was tested in the regression between antecedents of HWI and work outcomes. Considering mediating effects of HWI-WI, the full mediation was confirmed in case of regression between WE and TI, W - WE and JS, and W - WC and JS (after introducing employees' work effort (HWI-WI) into the regression, model $\beta$ turns into significant). The partial mediation is present between WE and JS (after introducing employees' work effort (HWI-WI) into the model $\beta$, it reduces but it does not turn into insignificant). In the case of mediating effects of HWI-TC, the full mediation was present between WE and TI (after introducing employees' time commitment (HWI-TC) into the model $\beta$ it turns into significant), $\mathrm{W}-\mathrm{WC}$ and JS and $\mathrm{W}-\mathrm{WC}$ and JB (after introducing employees' time commitment (HWI-TC) into the model $\beta$ it turns into insignificant). The results are shown in Table 6.

Table no. 6. Mediating effect of heavy work investment in regression between work engagement, workaholism, income satisfaction and work outcomes

\begin{tabular}{|c|c|c|c|c|c|c|c|c|c|}
\hline \multicolumn{9}{|c|}{ Work intensity (HWI) } \\
\hline \multirow{2}{*}{ Independent } & Dependent & \multicolumn{3}{|c|}{ Model 1 } & \multicolumn{3}{c|}{ Model 2 } & \\
\cline { 2 - 10 } & & $\mathbf{R}^{\mathbf{2}}$ & $\mathbf{F}$ & $\mathbf{p}$ & $\mathbf{B}$ & $\mathbf{R}^{\mathbf{2}}$ & $\mathbf{F}$ & $\mathbf{p}$ & $\boldsymbol{\beta}$ \\
\hline \multirow{4}{*}{$\begin{array}{c}\text { Work } \\
\text { Engagement }\end{array}$} & $\begin{array}{c}\text { Job } \\
\text { Satisfaction }\end{array}$ & .265 & 64.333 & .000 & $.515^{* *}$ & .284 & 35.065 & .000 & $.361^{* *}$ \\
\cline { 2 - 11 } & $\begin{array}{c}\text { Turnover } \\
\text { Intention }\end{array}$ & .002 & .282 & .596 & -.040 & .059 & 5.584 & .004 & $\mathbf{- . 3 1 4 ^ { * * }}$ \\
\cline { 2 - 11 } & Job Burnout & .000 & .059 & .809 & -.018 & .019 & 1.736 & .179 & -.175 \\
\hline Workaholism & Job & .002 & .345 & .558 & .044 & .274 & 33.253 & .000 & $\mathbf{- . 2 5 0 ^ { * * }}$ \\
\hline
\end{tabular}


Heavy Work Investment: A Good or Bad Phenomenon?

\begin{tabular}{|c|c|c|c|c|c|c|c|c|c|}
\hline \multicolumn{10}{|c|}{ Work intensity (HWI) } \\
\hline \multirow{2}{*}{ Independent } & \multirow{2}{*}{ Dependent } & \multicolumn{3}{|c|}{ Model 1} & \multirow[b]{2}{*}{ B } & \multicolumn{3}{|c|}{ Model 2} & \multirow[b]{2}{*}{$\boldsymbol{\beta}$} \\
\hline & & $\overline{\mathbf{R}^{2}}$ & $\mathbf{F}$ & $\mathbf{p}$ & & $\mathbf{R}^{2}$ & $\mathbf{F}$ & p & \\
\hline \multirow{3}{*}{$\begin{array}{l}\text { - Working } \\
\text { Excessively }\end{array}$} & Satisfaction & & & & & & & & \\
\hline & $\begin{array}{l}\text { Turnover } \\
\text { Intention }\end{array}$ & .088 & 17.096 & .000 & $.297^{* *}$ & .089 & 8.549 & .000 & $.309^{* *}$ \\
\hline & Job Burnout & .167 & 35.597 & .000 & $.409^{* *}$ & .188 & 20.408 & .000 & $.490^{* *}$ \\
\hline \multirow{3}{*}{$\begin{array}{c}\text { Workaholism } \\
\text { - Working } \\
\text { Compulsively }\end{array}$} & $\begin{array}{c}\text { Job } \\
\text { Satisfaction }\end{array}$ & .034 & 6.321 & .013 & $.185^{*}$ & .240 & 27.960 & .000 & $-.139^{* * *}$ \\
\hline & $\begin{array}{l}\text { Turnover } \\
\text { Intention }\end{array}$ & .052 & 9.748 & .002 & $.228^{* *}$ & .052 & 4.849 & .009 & $.231^{* *}$ \\
\hline & Job Burnout & .036 & 6.687 & .011 & $.190^{*}$ & .038 & 3.489 & .033 & $.220^{*}$ \\
\hline \multirow{3}{*}{$\begin{array}{c}\text { Income } \\
\text { Satisfaction }\end{array}$} & $\begin{array}{c}\text { Job } \\
\text { Satisfaction }\end{array}$ & .278 & 68.393 & .000 & $.527^{* *}$ & .431 & 67.023 & .000 & $.458^{* *}$ \\
\hline & $\begin{array}{l}\text { Turnover } \\
\text { Intention }\end{array}$ & .003 & .514 & .474 & -.054 & .022 & 2.031 & .134 & -.078 \\
\hline & Job Burnout & .008 & 1.412 & .236 & -.089 & .017 & 1.498 & .226 & -.105 \\
\hline \multicolumn{10}{|c|}{ Time commitment (HWI) } \\
\hline \multirow{2}{*}{ Independent } & \multirow{2}{*}{ Dependent } & \multicolumn{3}{|c|}{ Model 1} & & \multicolumn{3}{|c|}{ Model 2} & \\
\hline & & $\mathrm{R}^{2}$ & $\mathrm{~F}$ & $\mathrm{p}$ & $\beta$ & $\mathrm{R}^{2}$ & $\mathrm{~F}$ & $\mathrm{p}$ & $\beta$ \\
\hline \multirow{3}{*}{$\begin{array}{c}\text { Work } \\
\text { Engagement }\end{array}$} & $\begin{array}{c}\text { Job } \\
\text { Satisfaction }\end{array}$ & .265 & 64.333 & .000 & $.515^{* *}$ & .267 & 32.233 & .000 & $.538^{* * *}$ \\
\hline & $\begin{array}{l}\text { Turnover } \\
\text { Intention }\end{array}$ & .002 & .282 & .596 & -.040 & .049 & 4.538 & .012 & $-.171^{*}$ \\
\hline & Job Burnout & .000 & .059 & .809 & -.018 & .052 & 4.834 & .009 & -.155 \\
\hline \multirow{3}{*}{$\begin{array}{c}\text { Workaholism } \\
\text { - Working } \\
\text { Excessively }\end{array}$} & $\begin{array}{c}\text { Job } \\
\text { Satisfaction }\end{array}$ & .002 & .345 & .558 & .044 & .058 & 5.427 & .005 & -.067 \\
\hline & $\begin{array}{l}\text { Turnover } \\
\text { Intention }\end{array}$ & .088 & 17.096 & .000 & $.297^{* *}$ & .090 & 8.657 & .000 & $.279^{* *}$ \\
\hline & Job Burnout & .167 & 35.597 & .000 & $.409^{* *}$ & .167 & 17.705 & .000 & $.406^{* *}$ \\
\hline \multirow{3}{*}{$\begin{array}{c}\text { Workaholism } \\
\text { - Working } \\
\text { Compulsively }\end{array}$} & $\begin{array}{c}\text { Job } \\
\text { Satisfaction } \\
\end{array}$ & .034 & 6.321 & .000 & $.013^{*}$ & .066 & 6.274 & .002 & .114 \\
\hline & $\begin{array}{l}\text { Turnover } \\
\text { Intention } \\
\end{array}$ & .052 & 9.748 & .002 & $.228^{* *}$ & .060 & 5.603 & .004 & $.193^{*}$ \\
\hline & Job Burnout & .036 & 6.687 & .011 & $.190^{*}$ & .051 & 4.792 & .009 & $.141^{*}$ \\
\hline \multirow{3}{*}{$\begin{array}{c}\text { Income } \\
\text { Satisfaction }\end{array}$} & $\begin{array}{c}\text { Job } \\
\text { Satisfaction }\end{array}$ & .278 & 68.393 & .000 & $.527^{* *}$ & .318 & 41.297 & .000 & $.514^{* *}$ \\
\hline & $\begin{array}{l}\text { Turnover } \\
\text { Intention }\end{array}$ & .003 & .514 & .474 & .054 & .031 & 2.872 & .059 & -.064 \\
\hline & Job Burnout & .008 & 1.412 & .236 & -.089 & .044 & 4.094 & .018 & -.101 \\
\hline
\end{tabular}

\section{Discussion}

The study examined whether HWI (WI and TC) acted as a mediator in a relationship between antecedents (workaholism, work engagement, income satisfaction) and outcomes (job burnout, job satisfaction and turnover intention) of HWI. The results of this study gave insight into the nature of the relationship between examined constructs, which can be of great importance for the industry. The practical implications applicable to the industry will be discussed in the conclusion section. Considering work engagement as a positive type of hard work, it was expected that an increase in the work engagement of employees decreases their intent to leave the organization $(\mathrm{H} 2)$. Engaged employees enjoy their work activities, 
which reduces their intention to quit the company (Van Beek, 2013; Schaufeli and Bakker, 2004). The relationship between WE and TI in this study is negative, but it is not significant, which rejects $\mathrm{H} 2$. Work engagement supports the commitment to the organization, which further positively impacts responsible behavior, decreases the intention of leaving the organization. Although the influence of work engagement on the intention to leave the organization is not significant, employers should tend to diminish fluctuations of the employees in their organization to provide continuity in service quality. On the other hand, as usually unhappy and unsatisfied workaholics express lower satisfaction with their job, therefore, it is expected that an increase in workaholism leads to an increase in the intent to leave the organization (H6) as well as an increase in JS (H1). Linear regression shows that both dimensions of workaholism have a notable positive impact on the intention to quit, which is not different from the results obtained in previous studies (Burke and MacDermid, 1999; Choi, 2013; van Beek, et al., 2014; Andrews, 2019). These results confirm H6. Although several studies confirmed a positive effect of workaholism on JS ( $\mathrm{Ng}$, et al., 2005), the results of this study confirm only notable positive effects of W-WC on JS, which partially confirms H1. One of the possible explanations of this phenomenon could be that employees who work compulsively tend to achieve higher productivity. They direct their energy towards achieving and providing well-being, rather than achieving job satisfaction. Job burnout is classified as a negative outcome of HWI and there is even a correlation between absenteeism and burnout (Schaufeli, et al., 2009b) which can affect the productivity of employees. Based on previous findings that indicated the positive relationship between job burnout and workaholism (Schaufeli, et al., 2008, Tziner, et al., 2019) it was expected the results of previous studies to be confirmed. It was perceived that both sub-dimensions of workaholism (W-WE and W-WC) have a notable positive influence on JB, which confirms H3. It should be highlighted that employees' work engagement or other outcomes are not always triggered by challenge stressors. Maybe employees who work in various hospitality settings (hotels, restaurants, motels, or objects work especially during winter/summer season) will be unable to deal with their remaining burden. This can lead to negative outcomes, such as burnout and turnover intention. On the other hand, although it was expected that a negative relationship between WE and JB would be confirmed (Schaufeli, et al., 2002, Crawford, et al., 2010, Tziner, et al., 2019), the correlation between these two dimensions is negative but not significant, which rejects $\mathrm{H} 4$. Employees who experience burnout at work also experience concentration problems, a decrease in work engagement, and loss of feeling productive. To prevent employees from experiencing burnout, it is necessary to perceive the problem from two perspectives: the employer's and employee's perspective. The employee should accomplish tasks more systematically and set priorities, whereas the employer could contribute to minimizing burnout by application of efficient strategies (various benefits).

As one of the most examined constructs in the HR field, job satisfaction was treated as a positive work outcome in our study. If we start from the fact that job satisfaction is encouraged by work engagement (Alarcon and Edwards, 2011; Giallonardo, et al., 2010) it was expected that with the increase of WE, JS of employees increases. The obtained results are compatible with previous work (Schaufeli, et al., 2008; Van Beek, 2011) and confirm a positive relationship between these two dimensions and give support for H5. Work engagement is the basic concept which helps understand and describe qualitative and quantitative relationships between an organization and its employees. Work engagement is the framework in which people enjoy and believe in what they do and feel valuable for 
what they do (Wellins, et al., 2005). An engaged employee has a positive attitude towards the organization and its values, and also feels a higher level of satisfaction with the job. Besides, this study focused on investigating relations between WE, subdimensions of workaholism (WC and WE), income satisfaction, and work outcomes (JS, JB and TI) which are mediated by two subdimensions of HWI (HWI-TC and HWI-WI). The results showed that HWI-WI behaves as a full mediator of the relationship between WE and TI, W-WE and JS, W-WC and JS. The mediation effect of HWI in the relationship between IS and TI and IS and JB is not significant. The relationships between W-WE and TI and W-WC and TI are partially mediated by HWI-TI, which gives partial support for confirming H7. This means that if W-WE and W-WC increase, TI also increases, which is partially attained through the mediational mechanism of HWI-WI (effort investment). Although Rabenu et al. (2019) and Tzinner et al. (2019) found that HWI-WI behaves as a partial mediator between WE and JB, a significant mediation effect of HWI-WI between these two dimensions was not found in this research, which rejects H8. Moreover, HWI-TC does not behave as a mediator of the relationship between WE and JB at all, which confirms previously obtained results (Rabenu, et al., 2019) and rejects H9. The partial mediation effect of HWI-TC is confirmed between WE and JS, which partially confirms H10. Practically, this suggests that an increase in WE increases JS of employees but this increase is partially attained through the mediational mechanism of HWI-TC (investment of time).

\section{Conclusions}

In the long run, the organization needs excellent employees if it wants to grow further and achieve success. In the service sector, such as hospitality, employees are the core of the organization and there is a necessity of finding solutions not only to reduce both turnover and burnout but also to boost employees' satisfaction with work because it increases the commitment to the organization. Also, the nature of the working environment is important in forming an employee's satisfaction. As a result, the organization should strive to create a desirable work environment.

The usefulness of this study can be reflected through practical implications for hospitality managers. First of all, managers could design programs for evaluating and managing employees' burnout and intentions to leave the organization. More concrete, hospitality employees are faced with long working hours and a high level of effort in satisfying the needs of consumers. Given the fact that the invested effort is difficult to evaluate, the evaluation of time spent on performing a task is an important duty and responsibility of managers, due to adequate rewards and remuneration which motivate them to work effectively. Also, the managers should discover a technique that would measure the level of emotional effort of their employees, not only physical and mental effort. This requires a high level of managerial skills supported by emotional intelligence, for easier identification of emotional and physical burnout of employees. Moreover, managers should encourage two-way communication and create an environment that would urge the employees to express their ideas freely. Managers also have to pay attention to the cultural background and expectations of the population in the country in which they do business since it also impacts the level of work engagement and job satisfaction level. The cultural background of the employees and economic context (developed/developing countries) may strongly impact the perception of the employees and their attitudes towards the organization. Furthermore, it is required that managers understand what employees expect from the 
organization, with the regard to their background environment, all that to increase their work engagement. This is especially significant for hotel chains that operate in different countries and various cultural backgrounds. Under the condition of sudden changes, an organization needs to have loyal and engaged employees so that the adaptation to changes operates smoothly. Contrary to the work engagement of the employees, there is a group of employees that consider their job only as a duty and work only to justify their presence at work. Managers could solve this by using a personal approach to each employee to increase their motivation and productivity. Moreover, one of the serious consequences of workaholism is the fact that the energy of ambition is suppressed and manifested through hard and exhausting work. Workaholics are filled with destructive energy and depression, which cause stress and may lead to pathological changes to the body and soul. Taking into consideration the fact that workaholism is a sort of addiction for people escaping some other problems, and that stressed employees cannot offer quality service to customers, managers in the hospitality industry should recognize this disorder and help their employees balance personal lives by using employee assistance programs.

Yet, heavy work investment is the phenomenon that is an under-explored issue regarding work outcomes in the hospitality industry. The question is often raised whether HWI has positive or negative aspects of the phenomenon. In this research, two dimensions of HWI displayed different relationships with work outcomes. Both dimensions of HWI showed significant positive effects on JS. HWI-TC had a small but significant effect on TI and JB, while HWI-WI did not show any notable relationship with these work outcomes. If the obtained results are used as a basis, it can be induced that HWI in the hospitality industry shows positive signs of a phenomenon because of the small influence of HWI on negative work outcomes (job burnout and turnover intention). As shown in the literature review, the results confirmed the link between workaholism and negative work results such as burnout (Burke, 2000; Schaufeli, et al., 2009b) and intent to leave the organization (Choi, 2013; van Beek, et al., 2014; Andrews, 2019) while work engagement is linked with work results which are considered as positive, i.e. job contentment (Schaufeli, et al., 2008). A positive relationship between work engagement and job satisfaction implies that it is necessary to implement a strategy that would increase the level of work engagement of the total workforce within the organization.

The results of the research contribute to the literature related to this issue in the sense of better understanding the relationships between observed variables in the hospitality industry. Besides, the effects of both subdimensions of workaholism on work outcomes were observed separately in this research, which gave insight into the individual impact of each of the dimensions of workaholism on work outcomes. Finally, the research of this study expands the contemporary knowledge in this field by evaluating HWI as a mediational mechanism in the relationship between antecedents and work outcomes of HWI. Up to the present, this is the first empirical study assessing the relationships between the abovementioned constructs in the hospitality industry.

\section{Limitations and future directions}

Besides its contributions to knowledge in the field, this research has several constraints. First, what can be considered as the main constrain is the use of self-assessment measuring items for expressing the degree of experiencing some of the selected outcomes. This selfreporting used for measuring attitudes of employees can be affected by bias or unrealistic 
valuation, which can result in the smaller influence of variables than expected. Second, this research was conducted among employees in the hospitality industry in Serbia, so generalization is not possible. Also, the results of the research cannot be generalized due to the different cultural backgrounds of employees around the world (Shimazu and Schaufeli, 2009; Snir and Harpaz, 2006) which influence relationships between observed variables.

Also, according to the facts that workaholism is associated with different negative personality characteristics, such as neuroticism (Burke, et al., 2006), and that workaholics tend to be perfectionists (Kanai, et al., 1996), this issue should be further explored by adding personality characteristics to the applied model.

\section{References}

Ahmed, I. and Khan, M., 2015. Predicting Work Motivation Through Job Satisfaction and Turnover Intentions: The Explanatory Role of Heavy Work Investment. The Lahore Journal of Business, 4(1), pp.75-89.

Alarcon, G.M. and Edwards, J.M., 2011. The relationship of engagement, job satisfaction and turnover intentions. Stress and Health, 27(3), pp.294-298.

Andrews, V., 2019. The influence of workaholism and burnout on the intention to quit amongst academic employees at a selected university in the Western Cape. $\mathrm{PhD}$ dissertation: University of the Western Cape.

Bakker, A.B. and Demerouti, E., 2007. The Job Demands-Resources model: State of the art. Journal of Managerial Psychology, 22, pp.309-328.

Bartlett, M.S., 1950. Tests of significance in factor analysis. British Journal of Psychology, 3, pp.77-85.

Bartlett, M.S., 1951. A further note on tests of significance in factor analysis. British Journal of Psychology, 4, pp.1-2.

Brown, S.P. and Leigh, T.W., 1996. A new look at psychological climate and its relationship to job involvement, effort, and performance. Journal of Applied Psychology, 81(4), pp.358-368.

Bonebright, C.A., Clay, D.L. and Ankenmann, R.D., 2000. The relationship of workaholism with work-life conflict, life satisfaction, and purpose in life. Journal of counseling psychology, 47(4), p.469.

Boz, H., Yilmaz, O., Arslan, A., and Koc, E., 2016. A comparison of depression and turnover intentions of hotel employees in all-inclusive and non all-inclusive hotels. In: C. Avcikurt, M.S. Dinu, R. Efe, A. Soykan, \& N. Tetik (Eds), Global issues and trends in tourism (pp.372-382). Sofia, Bulgaria: St. Kliment Ohridski University Press.

Boz, H., and Yilmaz, O., 2017. An eye tracker analysis of the influence of applicant attractiveness on employee recruitment process: A neuromarketing study. Ecoforum Journal, 6(1), pp.354-363.

Britt, T.W., Castro, C.A. and Adler, A.B., 2005. Self-engagement, stressors, and health: A longitudinal study. Personality and Social Psychology Bulletin, 31(11), pp.1475-1486.

Burke, R.J., 1999. It's not how hard you work but how you work hard: Evaluating workaholism components. International Journal of Stress Management, 6(4), pp.225-239.

Burke, R.J. and MacDermid, G., 1999. Are workaholics job satisfied and successful in their careers?. Career Development International, 4(5), pp.277-282. 
Burke, R.J., 2000. Workaholism in organizations: psychological and physical well- being consequences. Stress Medicine, 16(1), pp.11-16.

Burke, R.J., and Matthiesen, S., 2004. Short communication: Workaholism among Norwegian journalists: Antecedents and consequences. Stress and Health, 20, pp.301-308.

Burke, R.J., and Fiksenbaum, L., 2009. Work motivations, satisfactions, and health among managers: Passion versus addiction. Cross-Cultural Research, 43(4), pp.349-365.

Burke, R.J., and Fiksenbaum, L., 2009, Work motivations, work outcomes, and health: Passion versus addiction. Journal of Business Ethics, 84(2), pp.257-263.

Cammann, C., Fichman, M., Jenkins, D., and Klesh, J., 1979. The Michigan organizational assessment questionnaire. Unpublished manuscript, University of Michigan, Ann Arbor.

Caruso, C.C., 2014. Negative impacts of shiftwork and long work hours. Rehabilitation Nursing, 39(1), pp.16-25.

Chen, Z., Sun, H., Lam, W., Hu, Q., Huo, Y., and Zhong, J.A., 2012. Chinese hotel employees in the smiling masks: Roles of job satisfaction, burnout, and supervisory support in relationships between emotional labor and performance. The International Journal of Human Resource Management, 23(4), pp.826-845.

Choi, Y., 2013. The differences between work engagement and workaholism, and organizational outcomes: An integrative model. Social Behavior and Personality: an international journal, 41(10), pp.1655-1665.

Crawford, E.R., LePine, J.A. and Rich, B.L., 2010. Linking job demands and resources to employee engagement and burnout: A theoretical extension and meta-analytic test. Journal of Applied Psychology, 95(5), pp.834-848.

Dembe, A.E., Erickson, J.B., Delbos, R.G., and Banks, S.M., 2005. The impact of overtime and long work hours on occupational injuries and illnesses: New evidence from the United States. Occupational and Environmental Medicine, 62(9), pp.588-597.

Fox, J., 2015. Applied regression analysis and generalized linear models. Thousand Oaks: Sage Publications.

Gamor, E., Amissah, E.F. and Boakye, K.A.A., 2014. Work-family conflict among hotel employees in Sekondi-Takoradi Metropolis, Ghana. Tourism Management Perspectives, 12 , pp.1-8.

García-Almeida, D. J., Fernández-Monroy, M., and Saá-Pérez, D., 2015. Dimensions of employee satisfaction as determinants of organizational commitment in the hotel industry. Human Factors and Ergonomics in Manufacturing \& Service Industries, 25(2), pp.153-165.

Garg, K., Dar, I.A., Mishra, M. 2017. Job satisfaction and Work engagement: A Study using private sector bank managers. Advances in Developing Human Resources, 20(1), pp.58-71.

Giallonardo, L.M., Wong, C.A. and Iwasiw, C.L., 2010. Authentic leadership of preceptors: predictor of new graduate nurses' work engagement and job satisfaction. Journal of nursing management, 18(8), pp.993-1003.

Green, F., 2008. Work effort and worker well-being in the age of affluence. In: R.J. Burke \& C.L. Cooper (Eds.), The long work hours culture: Causes, consequences and choices (pp.115-136). London: Emerald Group Publishing. 
Halbesleben, J.R.B., and Wheeler, A.R., 2008. The relative roles of engagement and embeddedness in predicting job performance and intention to leave. Work \& Stress, 22(3), pp.242-256.

Houlfort, N., Philippe, F., Valler R. and Me' nard, J., 2014. On passion and heavy work investment: personal and organizational outcomes. Journal of Managerial Psychology, 29(1), pp.25-45.

Hsieh, Y.C., and Eggers, P.D., 2010. Coping strategies used by lodging managers to balance work and personal lives: An exploratory study. International Journal of Hospitality \& Tourism Administration, 11(1), pp.39-58.

Huang, Z. J., and Miao, L., 2016. Illegitimate customer complaining behavior in hospitality service encounters: A frontline employee perspective. Journal of Hospitality \& Tourism Research, 40(6), pp.655-684.

Jung, H.S., Yoon, H.H., and Kim, Y.J., 2012. Effects of culinary employees' role stress on burnout and turnover intention in hotel industry: Moderating effects on employees' tenure. The Service Industries Journal, 32(13), pp.2145-2165.

Jung, H.S., Yoon, H.H. 2016. What does work meaning to hospitality employees? The effects of meaningful work on employees' organizational commitment: the mediating role of job engagement. International Journal of Hospitality Management, 53, pp.59-68.

Kaiser, H.F., 1974. An index of factorial simplicity. Psychometrika, 39(1), pp.31-36.

Kanai, A., Wakabayashi, M. and Fling, S., 1996. Workaholism among employees in Japanese corporations: an examination based on the Japanese version of the Workaholism Scales. Japanese Psychological Research, 38(4), pp.192-203.

Kang, J.W., Heo, J.H. and Kim, J.H., 2016. The followership of hotel employees and the relationship between occupational burnout, job stress, and customer orientation: Targeting the hotel service providers at luxury hotels. Tourism and Hospitality Research, 16(4), pp.345-358.

Karatepe, O.M., 2011. Do job resources moderate the effect of emotional dissonance on burnout? A study in the city of Ankara, Turkey. International Journal of Contemporary Hospitality Management, 23(1), pp.44-65.

Karatepe, O.M., Demir, E. 2014. Linking core self-evaluations and work engagement to work-family facilitation. International Journal of Contemporary Hospitality Management, 26(2), pp.307-323.

Koc, E., 2013. Power distance and its implications for upward communication and empowerment: Crisis management and recovery in hospitality services, The International Journal of Human Resource Management, 24(19), pp.3681-3696.

Koc, E., Bozkurt, G., 2017. Hospitality Employees' Future Expectations: Dissatisfaction, Stress, and Burnout. International Journal of Hospitality \& Tourism Administration, 18(4), pp.1-15.

Kuruuzum, A., Anafarta, N. and Irmak, S., 2008. Predictors of burnout among middle managers in the Turkish hospitality industry. International Journal of Contemporary Hospitality Management, 20(2), pp.186-198.

Kuvaas, B. and Dysvik, A., 2010. Exploring alternative relationships between perceived investment in employee development, perceived supervisor support and employee outcomes. Human Resource Management Journal, 20(2), pp.138-156. 
Lebrón, M., Tabak, F., Shkoler, O., and Rabenu, E., 2018. Counterproductive work behaviors toward organization and leader-member exchange: The mediating roles of emotional exhaustion and work engagement. Organization Management Journal, 15(4), pp.159-173.

Leung, S.M., Wu, L.Z., Chen, Y.Y. and Young, N., 2011. The impact of workplace ostracism in service organizations. International Journal of Hospitality Management, 30(4), pp.836-844.

Locke, E.A., 1976. The nature and causes of job satisfaction. In: M.D. Dunnette (Ed.), Handbook of industrial and organizational psychology (pp.1297-1349). Chicago: Rand McNally.

Lu, L., Lu, A.C.C., Gursoy, D., Neale, N.R. 2015. Work engagement, job satisfaction, and turnover intentions: A comparison between supervisor and line-level employees. International Journal of Contemporary Hospitality Management, 28(4), pp.737-761.

Maslach, C., 1993. Burnout: A multidimensional perspective. In: W.B. Schaufeli, C. Maslach, \& T. Marek (Eds.), Professional burnout: Recent developments in theory and research (pp.19-32). Washington, DC: Taylor \& Francis.

Maslach, C., Schaufelli, W.B., and Leiter, M.P., 2001. Job burnout. Annual Review of Psychology, 52(1), pp.397-422.

Mobaraki, H., Meymandi, R., Kamali, M. and Pourbakht, A., 2017. The relationship between quality of work life and job satisfaction among audiologists in Iran. Auditory and Vestibular Research, 26(4), pp.215-222.

Ng, T.W.H., Eby, L.T., Sorensen, K.L., and Feldman, D.C., 2005. Predictors of objective and subjective career success: A meta-analysis. Personnel Psychology, 58(2), pp.367-408.

Ng, T.W.H., Sorensen, K.L. and Feldman, D.C., 2007. Dimensions, antecedents, and consequences of workaholism: A conceptual integration and extension. Journal of Organizational Behavior, 28(1), pp.111-136.

Nunnally, J.C., 1978. Psychometric Theory. NewYork: McGraw Hill.

Onsøyen, L.E., Mykletun, R.J., and Steiro, T.J., 2009. Silenced and invisible: the workexperience of room-attendants in Norwegian hotels. Scand. J. Hospitality Tourism, 9(1), pp.81-102.

Pan, S.Y., 2018. Do workaholic hotel supervisors provide family supportive supervision? A role identity perspective. Journal of Hospitality Management, 68, pp.59-67.

Paeka, S., Schuckertb, M., Kimc, T. and Lee, G., 2015. Why is hospitality employees' psychological capital important? The effects of psychological capital on work engagement and employee morale. International Journal of Hospitality Management, 50, pp.9-26.

Park, J., Gursoy, D., 2012. Generation effects on work engagement among U.S. hotel employees. International Journal of Hospitality Management, 31(4), pp.1195-1202.

Pizam, A., 2015. Is the foodservice industry composed of only low-paid and unskilled jobs? International Journal of Hospitality Management, 50, pp.153-154.

Rabenu, E., Shkoler, O., Lebron, M. J., and Tabak, F., 2019. Heavy-work investment, job engagement, managerial role, person-organization value congruence, and burnout: A moderated-mediation analysis in USA and Israel. Current Psychology, pp.1-18.

Raediker, B., Janssen, D., Schomann, C., and Nachreiner, F., 2006. Extended working hours and health. Chronobiology International, 23(6), pp.1305-1316. 
Robinson, B.E., 1999. The Work Addiction Risk Test: Development of a tentative measure of workaholism. Perceptual and Motor Skills, 88(1), pp.199-210.

Sok, J., Blomme, R., De Ruiter, M., Tromp, D. and Lub, X.D., 2018. Home to work spillover and turnover intentions: The mediating role of training and development practices. European Journal of Training and Development, 42(3/4), pp.246-265.

Saks, A.M., 2006. Antecedents and consequences of employee engagement. Journal of managerial psychology, 21(7), pp.600-619.

Salanova, M., Agut, S., Peiro, J.M., 2005. Linking organizational resources and work engagement to employee performance and customer loyalty: The mediation of service climate. Journal of Applied Psychology, 90(6), pp.1217-1227.

Schaufeli, W.B., Salanova, M., González-Romá, V. and Bakker, A.B., 2002. The measurement of engagement and burnout: A two sample confirmatory factor analytic approach. Journal of Happiness studies, 3(1), pp.71-92.

Schaufeli, W.B., Taris, T.W and van Rhenen, W., 2008. Workaholism, burnout and engagement: Three of a kind or three different kinds of employee well-being. Applied Psychology: An International Review, 57(2), pp.173-203.

Schaufeli, W.B. and Bakker, A.B., 2004. Job demands, job resources, and their relationship with burnout and engagement: A multi- sample study. Journal of Organizational Behavior: The International Journal of Industrial, Occupational and Organizational Psychology and Behavior, 25(3), pp.293-315.

Schaufeli, W.B. and Salanova, M., 2007. Work engagement: an emerging psychological concept and its implications for organizations. Research in Social Issues in Management: Managing Social and Ethical issues in Organizations, 5, pp.135-177.

Schaufeli, W.B., Shimazu, A. and Taris, T.W., 2009a. Being driven to work excessively hard: The evaluation of a two-factor measure of workaholism in the Netherlands and Japan. Cross-cultural research, 43(4), pp.320-348.

Schaufeli WB, Leiter MP, Maslach C. 2009b. Burnout: thirty-five years of research and practice. Career Development International, 14(3), pp.204-220.

Shimazu, A. and Schaufeli, W.B., 2009. Is workaholism good or bad for employee wellbeing? The distinctiveness of workaholism and work engagement among Japanese employees. Industrial health, 47(5), pp.495-502.

Snir, R. And Harpaz, I. 2006. The workaholism phenomenon: a cross- national perspective. Career Development International, 11(5), pp.374-393

Snir, R., and Harpaz, I., 2012. Beyond workaholism: Towards a general model of heavy work investment. Human Resource Management Review, 22(3), pp.232-243.

Snir, R., and Harpaz, I., 2015. A general model of heavy work investment. In: I. Harpaz \& R. Snir (Eds.), Heavy work investment: Its nature, sources, outcomes, and future directions (pp.3-30). New York: Routledge.

Stimpfel, A.W., Sloane, D.M., and Aiken, L.H., 2012. The longer the shifts for hospital nurses, the higher the levels of burnout and patient dissatisfaction. Health Affairs, 31(11), pp.2501-2509.

Spence, J.T., and Robbins, A.S., 1992. Workaholism: Definition, measurement, and preliminary results. Journal of Personality Assessment, 58(1), pp.160-178. 
Tourigny, L., Baba, V.V., Han., J., and Wang, X., 2013. Emotional exhaustion and job performance: The mediating role of organizational commitment. The International Journal of Human Resource Management, 24(3), pp.514-532.

Tziner, A., Buzea, C., Rabenu, E., Shkoler, O. and Truța, C., 2019. Understanding the relationship between antecedents of heavy work investment (HWI) and burnout. Amfiteatru Economic, 21(50), pp.153-176.

Ulucan, E. and Yavuz, N., 2019. The effect of workaholism and work-family conflict on burnout in hospitality enterprises. The Journal of Academic Social Science, 89(7), pp.529-543.

Van Beek, I., Taris, T.W. and Schaufeli, W.B., 2011.Workaholic and work engaged employees: dead ringers or worlds apart? Journal of Occupational Health Psychology, 16(4), pp.468-482.

Van Beek, I., Hu, Q., Schaufeli, W.B., Taris, T.W. and Schreurs, B.H.J., 2012. For fun, love, or money: what drives workaholic, engaged, and burned-out employees at work?, Applied Psychology: An International Review, 61, pp.30-55.

Van Beek, I., Taris, T.W., Schaufeli, W.B. and Brenninkmeijer, V., 2013. Heavy work investment: Its motivational make-up and outcomes. Journal of Managerial Psychology, 29(1), pp.46-62.

Van Beek, I., Kranenburg, I., Reijseger, G., Taris, T. and Schaufeli, W., 2014. Work engagement and workaholism: the role of psychological need satisfaction and consequences for performance. Gedrag \& Organisatie, 27(4), pp.385-406.

Vandenberghe, C. and Bentein, K., 2009. A closer look at the relationship between affective commitment to supervisors and organizations and turnover. Journal of Occupational and Organizational Psychology, 82(2), pp.331-348.

Van Iddekinge, C. H., Roth, P. L., Putka, D. J. and Lanivich, S.E., 2011. Are you interested? A meta-analysis of relations between vocational interests and employee performance and turnover. Journal of Applied Psychology, 96(6), pp.1167-1194.

Wellins, R.S., Bernthal, P. and Phelps, M., 2005. Employee engagement: The key to realizing competitive advantage. Development Dimensions International, 5, pp.1-31.

Yildiz, S., Gulluce, A. and Saglik, E., 2014. Does Emotional Labor Influence Burnout? A Case Study for Turkey on Five Star Hotel Employees. International Journal of Arts and Commerce, 3(3), pp.108-123.

Yeh, C.M., 2013. Tourism involvement, work engagement and job satisfaction among front-line hotel employees. Annals of Tourism Research, 42, pp.214-239.

Zaibaf, M., Taherikia, F. and Fakharian, M., 2013. Effect of perceived service quality on customer satisfaction in hospitality industry: Gronroos' service quality model development. Journal of Hospitality Marketing \& Management, 22(5), pp.490-504.

Zopiatis, A., Constanti, P., Theocharous, A.L., Tepavcevic. J, 2014. Job involvement, commitment, satisfaction and turnover: evidence form hotel employees in Cyprus. Tourism Management, 41, pp.129-140. 